\title{
Posterior Reversible Encephalopathy Syndrome in a Thalassemia Minor Woman after in vitro Fertilization
}

\author{
(D) Pınar GELENER1, iD Süha Halil AKPINAR²
}

${ }^{1}$ University of Kyrenia, Faculty of Medicine, Department of Neurology, Kyrenia, North Cyprus

${ }^{2}$ Near East University Faculty of Medicine, Department of Neurology, Nicosia, North Cyprus

\begin{abstract}
Posterior reverzibl ensefalopati (PRES) sendromu, nöbet, başağrısı, vizüel defisitler, fokal nörolojik bulgular ile karakterize, bilinç düzeyinin değişik derecelerde etkilenebildiği bir klinik antitedir. Literatüre göre, preaklampsi ile ilişkili PRES olguları daha iyi seyirli ve kendisini sınırlayan bir tablo gibi görünse de, in vitro fertilizasyon sonrası gelişen gebelikler sonrası gelişen PRES seyri ile ilgili veriler oldukça sınırlıdır. Bu olgu sunumunda, in vitro fertilizasyon sonrası ikiz gebelikle sonuçlanan gebelik dönemi sonrası, doğum eyleminin hemen sonrasında PRES gelişen 40 yaşında talasemi minör tanılı bir primigravida tartışılmışıır.
\end{abstract}

Anahtar Sözcükler: Posterior reveverzibl ensefalopati, in vitro fertilizasyon, talasemi

\section{Introduction}

Posterior reversible encephalopathy syndrome (PRES) as a complication of severe preeclampsia occurs most frequently in the third trimester of pregnancy and may evolve unfavourable outcomes increasing fetal and maternal mortality (1). Herein, we report a thalassemia minor patient with twin pregnancy who developed PRES. Most studies indicate that IVF-pregnancies and oocyte donation are associated with more obstetric complications increasing risk of maternal mortality when compared to naturally conceived pregnancies (2-5).

\section{Case Report}

We present a case of 40-year-old thalassemia minor primigravida who underwent in vitro fertilization (IVF) ensuing twin pregnancy. At the gestation age of 36 weeks and 3 days, cesarean section $(\mathrm{c} / \mathrm{s})$ was performed under spinal anesthesia. The new borns were two girls weighing 2130 and $2060 \mathrm{~g}$. Two hours after the $\mathrm{c} / \mathrm{s}$, patient experienced generalized tonic clonic seizures and lost her consciousness.
She was reported to have high arterial pressure up to $180 / 110 \mathrm{mmHg}$ during $\mathrm{c} / \mathrm{s}$. She did not have any history of hypertension and documented blood pressures during her pregnancy were normal.

Systemic examination was unremarkable except the high blood pressure (around 170/100mmHg). Neurologic examination after postictal period revealed loss of vision in both eyes with regard to perception of hand movements. Pupillary reactions and fundoscopy were normal and plantar reflexes were flexor. Biochemical blood tests including liver and renal functions, coagulation and blood count were all normal except urine examination which showed $1+$ proteinuria.

Cranial magnetic resonance imaging (Philips Medical Systems 1.5 Tesla, The Netherlands) showed diffusion restriction (Figure 1) with focal ADC map hipointensity involving bilateral occipital lobes and FLAIR hyperintensities were spotted which were suggestive of typical PRES findings (Figure 2,3) .

Treatment with magnesium sulphate (Onfarma, Samsun, Turkey) infusion was started immediately. She required addition

Address for Correspondence: PInar GELENER, University of Kyrenia, Faculty of Medicine, Department of Neurology, Kyrenia, North Cyprus

Received: 07.03.2018

Phone: +90 3926751000 E-mail: pinar.gelenerarsal@neu.edu.tr ORCID ID: orcid.org/0000-0002-8681-9847

Accepted: 26.10.2018

Cite this article as: Gelener P, Akpınar HS. Posterior Reversible Encephalopathy Syndrome in a Thalassemia Minor Woman after in vitro Fertilization. Bezmialem Science 2019;7(2):164-6. 
of calcium channel blocker and beta blockers to restore blood pressure. Levetiracetam (UCB Pharma, İstanbul, Turkey) was also added and the dose increased to optimal level till magnesium infusion was stopped. The patient gained full consciousness after seizure and aggressive blood pressure control. She was discharged from intensive care unit to neurology service next day.

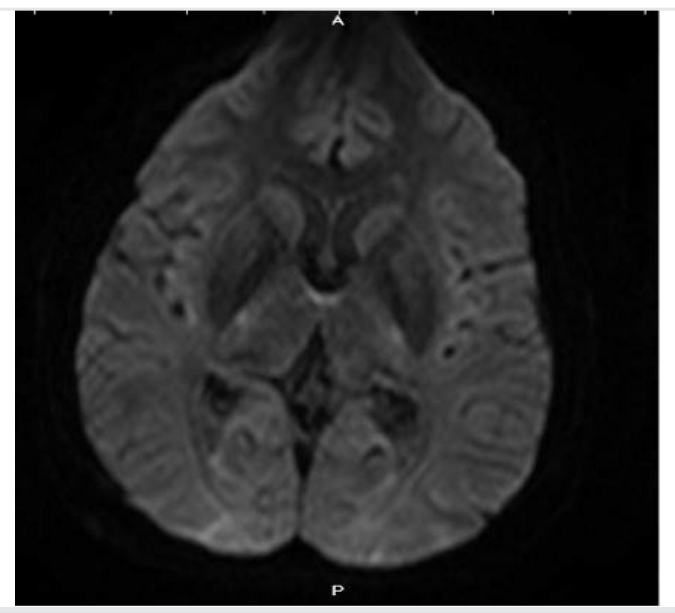

Figure 1. Diffusion restriction at bilateral occipital lobes at DW scan

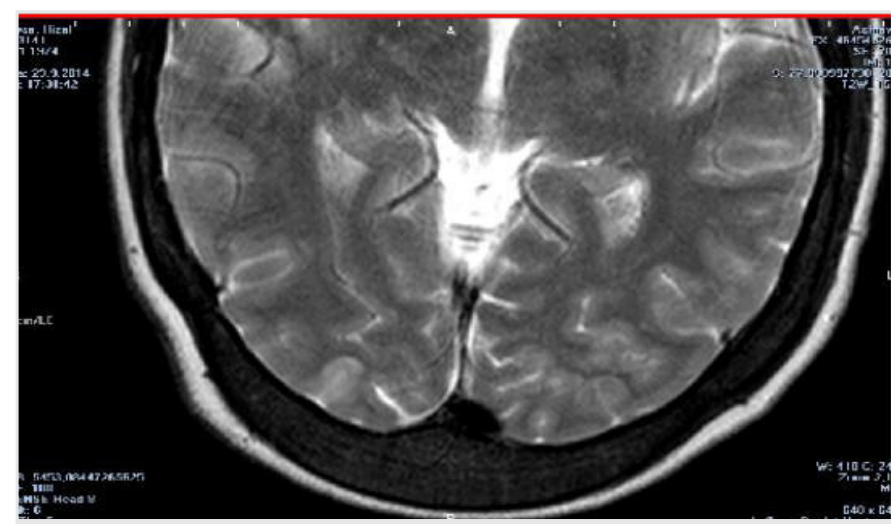

Figure 2. FLAIR hyperintensities at bilateral occipital lobes with cortical thickening on right

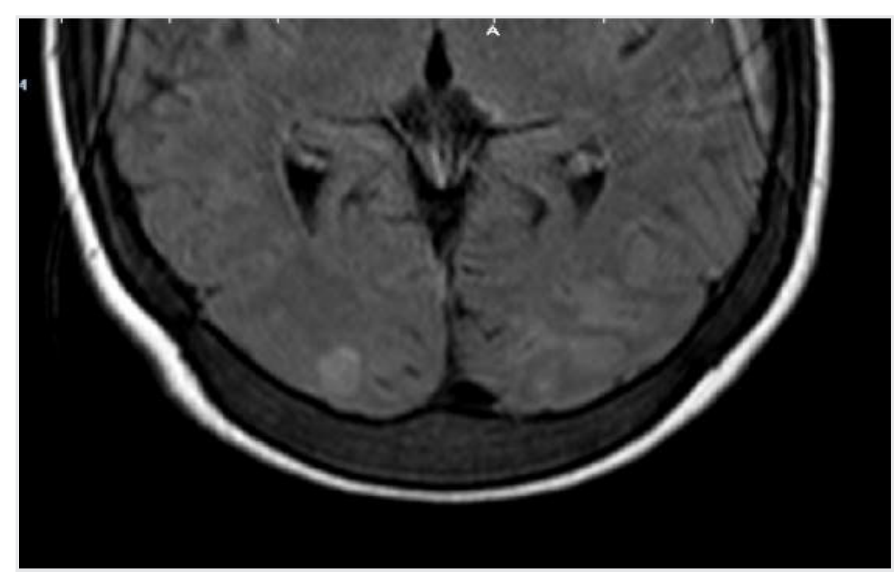

Figure 3. T2 hyperintensities at bilateral occipital lobes with cortical thickening on right Diploe thickening at cranial bones in Thalasemia minor patient
Patient's clinical condition was stabilized but the next day she had difficulty in breathing and oxygen saturation from the pulse oximetry decreased till 75 . She was diagnosed to have pulmonary embolism. Low molecular weighted heparine was initiated after diagnosis.

All the symptoms and improved and disappeared completely on day 6 of hospitalization and she was discharged. The MRI was reviewed 2 weeks later which showed complete disappearance of the previous imaging findings. Levetiracetam was stopped gradually in the third month as both MRI and EEG were normal. She currently has no discomfort.

The informed consent was taken from the patient.

\section{Discussion}

PRES is a clinical entity characterized by acute or subacute clinical presentation of altered mental status, encephalopathy, headache, new onset seizures, and visual disturbances.

Neuroradiologic findings are essential in diagnose of PRES. The typical MRI lesions are symmetrical white matter vasogenic edema, usually located parieto-occipital region sparing calcarine and paramedian regions, which may show progression to cytotoxic edema, infarctions, hemorrhages, laminar necroses and glioses (2).

Although PRES is generally assumed to be related to hypertensive encephalopathy, there is a long list of predisposing factors and diseases including inflammatory or auto-immune diseases, electrolyte imbalances, spinal injuries, vasoactive drugs and chemotherapy agents, preeclampsia and eclampsia. Preeclampsia is a significant, multifactorial, multiorgan disease which is one of the five major causes of maternal death worldwide (2). It is classically characterized by increase in blood pressure and proteinuria in the third trimester. It is known that IVF, twin pregnancy and women being pregnant at advanced age are all risk factors for pre-eclampsia. IVF-pregnancies are associated with more obstetric complications and increased risk of maternal mortality than naturally conceived pregnancies. An increased risk of preeclampsia, gestational hypertension and pregnancy induced hypertension especially in oocyte-donated pregnancies, when compared in vitro fertilization with own oocytes and natural conception. For nulliparous women this risk is even more significant (3). In another study, the risk factors independently associated with preeclampsia in twin pregnancies were reported as egg donation and pre pregnancy obesity (4).

It is shown that PRES relating to preeclampsia tends to present better evolution and reversibility. There is very limited data in the literature about the prognosis in PRES cases related to preeclampsia after IVF treatment. There are reports of maternal death after oocyte donation due to neurologic complications and pregnancy terminations at early gestational age due to preeclampsia (5).

PRES is a life-threatening neuro-radiological entity which tends to be reversible once the underlying cause is identified and treated 
early. It should be kept in mind that in vitro fertilization, twin pregnancy, nulliparity and advanced maternal age may increase the risk of developing this entity as stated in our case.

\section{Ethics}

Informed Consent: A consent form was completed by all participants.

Peer Review: Externally and internally peer-reviewed.

\section{Authorship Contributions}

Analysis or Interpretation: S.A., Literature Search: P.G., Writing: P.G.

Conflict of Interest: No conflict of interest was declared by the authors.

Financial Disclosure: The authors declared that this study received no financial support.

\section{References}

1. Liman TG, Bohner G, Heuschmann PU, Scheel M, Endres M, Siebert E. Clinical and radiological differences in posterior reversible encephalopathy syndrome between patients with preeclampsiaeclampsia and other predisposing diseases. Eur J Neurol 2012;19:93543.

2. Pereira PR, Pinho J, Rodrigues M, Rocha J, Sousa F, Amorim J, et al. Clinical, imagiological and etiological spectrum of posterior reversible encephalopathy syndrome. Arq Neuropsiquiatr 2015;73:36-40.

3. Masoudian P, Nasr A, Nanassy J, Fung-Kee-Fung K, Bainbridge SA, El Demellawy. Oocyte donation pregnancies and the risk of preeclampsia or gestational hypertension: a systematic review and metaanalysis. Am J Obstet Gynecol 2016;214:328-39.

4. Fox NS, Roman AS, Saltzman DH, Hourizadeh T, Hastings J, Rebarber A. Risk factors for preeclampsia in twin pregnancies. Am J Perinatol 2014;31:163-6.

5. Liman TG, Bohner G, Heuschmann PU, Scheel M, Endres M, Siebert E. Clinical and radiological differences in posterior reversible encephalopathy syndrome between patients with preeclampsiaeclampsia and other predisposing diseases. Eur J Neurol 2012;19:93543. 